\title{
Synergistic Trial Model of Four Coadministration of Medicinal Herbs on Malaria infected Mice
}

\author{
ANIGBORO, AA \\ Department of Biochemistry, Faculty of Science, Delta State University, P.M.B.001, Abraka, Nigeria. \\ Email: akposanigboro@yahoo.co.uk; akposanigboro@gmail.comTel: +2348034230386.
}

\begin{abstract}
Azadirachta indica (neem tree), Vernonia amygdalina (bitter leaf), Eucalyptus camaldulensis (red gum), and Bambusa vulgaris (bamboo) are locally employed for the management of malaria infection. This study examined the synergistic action of these four co-administered aqueous leaf extracts on malaria infected mice. There was a noticeable reduction in the parasitemia levels from 62 to $8 \%$ when the administration of the extracts given. The electrolytes (sodium, calcium, phosphorus and chloride) levels in the serum returned close to normal in the treated animals. There was a marked difference in alanine aminotransferase (ALT), aspartate aminotransferase (AST), alkaline phosphatase (ALP), and gamma glutamyl-transferase (GGT) activities in serum of the treated mice in comparison with the control groups $(\mathrm{P}<0.05)$. Total and direct bilirubin levels also increased in animals treated with the extract the activity of antioxidants enzymes such as glutathione transferase (GST), catalase (CAT), glutathione peroxidase (GPx), and superoxide dismutase (SOD) of the treated animals increased relative to the control groups $(\mathrm{P}<0.05)$. Glutathione $(\mathrm{GSH})$ levels increased upon the intake of the extract by the groups treated extract. The levels of lipid peroxidation (MDA) and nitric oxide (NO) reduced in animals treated with the extract. Urea, creatinine and uric acid in the serum were brought towards normalization after the intake of the various extracts. These observations are indication of antimalarial and protective roles of the four co-administered extracts on parasitized mice.
\end{abstract}

\section{DOI: https://dx.doi.org/10.4314/jasem.v22i7.22}

Copyright: Copyright $(2) 2018$ Anigboro. This is an open access article distributed under the Creative Commons Attribution License (CCL), which permits unrestricted use, distribution, and reproduction in any medium, provided the original work is properly cited.

Dates: Received: 15 May 2018; Revised: 20 June: 2018; Accepted: 30 June 2018

Key words: Medicinal plants, synergy, antimalarial, chemoprevention.

Malaria is one of the most prevalent and endemic human infectious diseases in the world, with around 214 million cases a year (WHO, 2015). Approximately 3.2 billion people live in areas at risk of malaria attack. Populations of the unfortunate countries are the most vulnerable (Marrelli and Brotto, 2016). Over 800 children is lost to malaria each day in Africa (WHO, 2015). In addition, malaria cases have been reported in non-endemic countries as a result of migration (Sharma et al., 2016; Marrelli and Brotto, 2016). Malaria in humans can be caused by five different species and they include Plasmodium falciparum, Plasmodium vivax, Plasmodium ovale, Plasmodium malariae and Plasmodium knowlesi (Odeghe et al., 2012). Plasmodium falciparum can lead to spartan malaria and death if sufficient treatment is not provided nippily (Maan et al., 2017). The pathogenesis machineries of several diseases caused by protozoan and nematode parasites have revealed detrimental effect on cardiac and skeletal muscles, organ damage as well as severe headache. Coronary artery obstruction has also been reported by plasmodium falciparum infection (Bott-Silverman and Aksut, 2015). Malaria pathogenesis is a sequential way by which malaria parasites can lead to illness, abnormal function, or damage in their animal or human hosts (Marrelli and Brotto, 2016). Symptoms include recurring incidents of shudders, intense fever, sweating, headache, malaise, fatigue, body aches, nausea, and vomiting. Cerebral coma, seizures, severe anemia, respiratory distress, kidney and liver failure, cardiovascular failure, and shock are symptoms of severe case of malaria particularly in children and expectant mothers (Stanley et al., 2013; Marrelli and Brotto, 2016). Antimalarial agents used include lonart, artesunate, artemisinin-based combination therapy (ACT) etc.

Phytomedicines are crude drugs extracted from plants employed in the treatment of malaria infection. They are relatively cheaper than the conventional drugs. Crude drugs are locally sourced and are readily available for the treatment of severe malaria. Several authors have investigated different phytomedical plant potentials for treatment of malarial parasite. Somsak et al. (2015) and Chaisawangwong and Gritsanapan, (2013) investigated Azadirachta indica (neem tree) for the treatment of some extreme conditions related to oxidative stress, such as inflammation and skin diseases, rheumatic, arthritic disorders, and treatment 
of fever and diabetes. Vernonia amygdalina (bitter leaf) has been investigated for various ailments (Ekpo and Ekanemesang, 2016; Oyedeji et al., 2013). The leaves of Eucalyptus was studied (Adeniyi et al., 2016; Takasaki et al. 1990; Nagpal et al., 2010) for its importance in the treatment of bronchial and pulmonary bacterial and viral infections and as antimicrobial agents. In Asian countries, diverse parts of bamboo have been involved treatment of hypertension, arteriosclerosis, cardiovascular disease and certain forms of cancer, antioxidant activities and are non-toxic (Ambika and Rajagopal, 2017). Traditionally, shoots of bamboo is use to increase the movement of food in the gastro -intestinal tract and in the prevention and cure of cardiovascular diseases and cancers. Currently, researchers have demonstrated that the shoots have a number of health benefits, such as weight loss, hypocholestorolemia, hypoglycaemia, anticarcinogenic improvement of appetite and digestion. It is believed that bamboo extract may have antioxidant properties and provide anti-inflammatory effects (Khan and Hemalatha, 2015). The purpose of this work is to assess the antimalarial and protective action of coadministration of aqueous leaf extracts of Azadirachta indica, Vernonia amydalina, Eucalyptus camaldulensis and Bambusa vulgaris on acute alteration in serum electrolytes, liver biomarkers, and antioxidants of malaria infected mice.

\section{MATERIALS AND METHODS}

Chemical and Reagents: Lonart (antimalarial drug), and all other reagents used for this study were obtained from Alpha Chimika, Mumbia, China.

Experimental Animals:Adult male albino mice of 3 to 4 months weighing between $30-35 \mathrm{~g}$ were obtained from the animal house, Faculty of Basic Medical Sciences, Delta State University, Abraka, Nigeria. They were fed with grower marsh obtained from Dutch Farm Limited, Abraka and water ad libitum. They were acclimatized for one week.

Collection and Identification of Plant Material: Fresh leaves of A. indica and B. vulgaris (Bamboo) were collected from Abraka, Ethiope East Local Government Area, Delta State. Similarly, fresh leaves of V. amydalina and E. camaldulensis were collected from Sapele, in Delta State and Ajaokuta in Kogi State respectively. They were identified at the Department of Botany, Delta State University, Abraka, Nigeria.

Preparation of Extracts: The leaves were lapped to remove contaminants and air-dried for about three weeks. Thereafter, they were grinded to fine powder using Waren blender. 200g of $A$. indica and 700g of $B$. vulgaris (powdered forms) was soaked in $800 \mathrm{ml}$
(0.8L) and $2800 \mathrm{ml}$ (2.8L) of distilled water respectively in a ratio $1: 4$. In the same vein, $500 \mathrm{~g}$ of $V$. amydalina and $800 \mathrm{~g}$ of $E$. camaldulensis was also soak in $2000 \mathrm{ml}(2 \mathrm{~L})$ and $3200 \mathrm{ml}(3.2 \mathrm{~L})$ of distilled water respectively in the same ratio. It was macerated after $48 \mathrm{hrs}$ to obtain the crude extracts. This was followed by filtration using Whatman No110 filter paper. The purified crude was then concentrated using a vacuum rotary evaporator at reduced temperature $\left(50^{\circ} \mathrm{C}\right)$ and bathe at $40^{\circ} \mathrm{C}$. This yielded a dark brown concentrated extracts of $A$. indica $58.5 \mathrm{~g}(29.25 \% \mathrm{w} / \mathrm{w}), B$. vulgaris $29 \mathrm{~g}(4.14 \% \mathrm{w} / \mathrm{w})$, V. amygdalina $125 \mathrm{~g}(25 \% \mathrm{w} / \mathrm{w})$ and E. camaldulensis $43 \mathrm{~g}(5.375 \% \mathrm{w} / \mathrm{w})$. The obtained crude extracts was packaged in airtight plastic containers and stored at $4^{\circ} \mathrm{C}$ prior administration.

Inoculation: The mice were inoculated intraperitoneally with Plasmodium berghei and baseline was established as published by Ekpo and Ekanemesang (2016) and Kadry et al. (2013).

Experimental design: A total of forty-five (45) mice were used for this research and were grouped into nine (9) of five (5) mice each as follows. The malarial load was determined prior treatment as shown in Table 1.

Table 1. Experimental design

\begin{tabular}{l}
\hline Treatment group \\
\hline Negative control(NC): Normal healthy rats + No treatment \\
Positive control (PC): Malarial sick rats + No treatment \\
$\mathrm{AB}:(50 \mathrm{mg} / \mathrm{kg}$ of $\mathrm{A}+50 \mathrm{mg} / \mathrm{kg}$ of $\mathrm{B})$ \\
$\mathrm{AC}:(50 \mathrm{mg} / \mathrm{kg}$ of $\mathrm{A}+50 \mathrm{mg} / \mathrm{kg}$ of $\mathrm{C})$ \\
$\mathrm{AD}:(50 \mathrm{mg} / \mathrm{kg}$ of $\mathrm{A}+50 \mathrm{mg} / \mathrm{kg}$ of D) \\
$\mathrm{CD}:(50 \mathrm{mg} / \mathrm{kg}$ of $\mathrm{C}+50 \mathrm{mg} / \mathrm{kg}$ of $\mathrm{D})$ \\
$\mathrm{BCL}:(50 \mathrm{mg} / \mathrm{kg}$ of $\mathrm{B}+50 \mathrm{mg} / \mathrm{kg}$ of $\mathrm{C})$ \\
$\mathrm{BD}:(50 \mathrm{mg} / \mathrm{kg}$ of $\mathrm{B}+50 \mathrm{mg} / \mathrm{kg}$ of $\mathrm{D})$ \\
Standard drug (STD): $(\mathrm{Lonart} 100 \mathrm{mg} / \mathrm{kg})$ \\
Where A= Azadirachta indica; B= Vernonia amygdalina $; \mathrm{C}=$ \\
Eucalyptus camaldulensis; $\mathrm{D}=$ Bambusa vulgaris.
\end{tabular}

Collection of Sample: The mice were sacrificed by cervical dislocation and blood sample was collected using $5 \mathrm{ml}$ syringe from each mouse. Samples were emptied into anticoagulant containers while some of the samples were equally placed in universal containers (serum enzymes) and assayed biochemically.

Liver Antioxidants: The liver from each animal was excised, rinsed in ice cold $0.25 \mathrm{M}$ sucrose solution and $10 \% \mathrm{w} / \mathrm{v}$ homogenate was prepared in $0.05 \mathrm{M}$ phosphate buffer ( $\mathrm{pH} 7.4$ ) and centrifuged at $3,000 \mathrm{~g}$ for $60 \mathrm{~min}$ at $4^{\circ} \mathrm{C}$. The supernatant was collected and assayed for oxidative stress parameters such as glutathione (GSH) (Beutler et al., 1963), glutathione peroxidase (GPx) (Mantha et al., 1993), superoxide dismutase (SOD) (Misra and Fridovich, 1972), 
glutathione-S-transferase (GST) and nitric oxide (NO) (Ellman, 1951), catalase (CAT) and lipid peroxidation measured as malondialdehyde (MDA) concentration (Chance and Maehly, 1955).

Determination of Biochemical Parameters: Estimation of liver markers [alanine aminotransferase (ALT), aspartate aminotransferase (AST), alkaline phosphatase (ALP), gamma glutamyltransferase (GGT), direct bilirubin (DB) and total bilirubin (TB)], serum electrolytes (calcium, sodium, phosphorus and chloride), and renal markers (urea, creatinine and uric acid) were carried out using Prietest easylab Biochemistry Analyser, Lab Tech, England.

Statistical Analysis: The data was analysed using a one-way analysis of variance (ANOVA) with the aid of a statistical software (SPSS version 21) and differences in mean values with $\mathrm{p}<0.05$ were considered significant. The results are represented as Mean \pm standard deviation.

\section{RESULTS AND DISCUSSION}

The reason for evaluating the consequence of coadministration of Azadirachta indica, Vernonia amygdalina, Eucalyptus camaldulensis and Bambusa vulgaris aqueous leaf extracts on liver antioxidants (GST, CAT, SOD, GPx, MDA GSH and NO scavenging capacity), renal parameters (urea, uric acid and creatinine), serum electrolytes (sodium, calcium, phosphorus and chloride), and liver function biomarkers (ALT, AST, ALP, GGT, DB and TB) activity during malaria infection in mice was to establish the possible usefulness of such intervention in the treatment and management of malaria parasite infection. Prior to the treatment of the inoculated mice, the parasite load was very high $62 \%$ (Table 2 ).

Table 2. Level of parasitemia in malarial sick mice after treatment with different combinations of aqueous extracts of Azadirachta indica, Vernonia amygdalina, Eucalyptus camaldulensis, and Bambusa vulgaris.

\begin{tabular}{lll}
\hline Group & MP Load & MP $(\%)$ \\
\hline NC & $0 \pm 0^{\mathrm{a}}$ & $0 \pm 0^{\mathrm{a}}$ \\
PC & $15.50 \pm 1.44^{\mathrm{b}}$ & $62 \pm 5.77^{\mathrm{b}}$ \\
AB & $7.00 \pm 1.63^{\mathrm{d}}$ & $28.00 \pm 6.53^{\mathrm{d}}$ \\
AC & $10.00 \pm 0.00^{\mathrm{e}}$ & $40.00 \pm 0.00^{\mathrm{e}}$ \\
AD & $13.00 \pm 0.00^{\mathrm{f}}$ & $52.00 \pm 0.00^{\mathrm{f}}$ \\
BC & $2.00 \pm 0.00^{\mathrm{g}}$ & $8.00 \pm 0.00^{\mathrm{g}}$ \\
BD & $5.00 \pm 0.00^{\mathrm{h}}$ & $20.00 \pm 0.00^{\mathrm{h}}$ \\
CD & $6.00 \pm 0.00^{\mathrm{c}}$ & $24.00 \pm 0.00^{\mathrm{c}}$ \\
STD & $6.00 \pm 1.63^{\mathrm{c}}$ & $24.00 \pm 6.53^{\mathrm{c}}$
\end{tabular}

$\mathrm{NC}=$ Negative control; $\mathrm{PC}=$ Positive control; $\mathrm{A}=$ Azadirachta indica $; \mathrm{B}=$ Vernonia amygdalina $; \mathrm{C}=$ Eucalyptus camaldulensis $; \mathrm{D}=$ Bambusa vulgaris; STD, Standard antimalarial drug (Lonart); MP, Malaria parasites. Values are expressed in Mean \pm Standard error of mean (SEM).
But as the extracts were being given, there was marked reduction in the treated animals in relation to the positive groups. The reduction was markedly at the group administered with combined extracts of $V$. amygdalina (B) and E. camaldulensis (C) herein referred to as BC representing $8 \%$. Again, the reduction was also observed in all the treated groups when compared with the positive group. This may be attributed to the antiplasmodial activities of the various aqueous extracts. This finding agrees with the reports of Ekpo and Ekanemesang (2016), Somsak et al., (2015) and Cissy et al., (2016). Alterations in serum electrolytes serve as a signal of abnormalities in parasitized cells. There was a noticeable difference in the serum concentrations of sodium, calcium, phosphorus and chloride of the treated groups in comparison with the control groups $(\mathrm{P}<0.05)$. This could be due to the presence of the above mentioned minerals in the various extracts which helped to restore the levels in parasitized mice towards normal (Table 3 ). This finding agrees with that of Omoregie and $\mathrm{Pal}$ (2016). Liver damage as a result of induced stress can be evaluated by measuring the activities of liver markers (ALT, AST, ALP, GGT) and the amount of direct bilirubin (DB) and total bilirubin (TB) released into the serum. These are potent indicators of the extent damage caused to the liver as a result of metabolic stress. There were elevated levels of ALT, AST, ALP and GGT in the serum of inoculated mice and a decrease in TB and DB. However, administration of the extracts showed a decrease in ALT, AST, ALP and GGT of the treated groups when compared with the control groups. TB and DB also increased significantly across the treated group groups when compared with the control groups (Table 4). This could be attributed to the presence of some phytochemicals inherent in the extract that are hepatoprotective (Anigboro et al., 2014; Aganbi et al., 2015). Again, it is an indication of the therapeutic action of the various extract combinations on the liver of Plasmodium berghei inoculated mice. Antioxidants defend the cell from destruction caused by stress. They scavenge reactive oxygen species (ROS) and nitrogen species (RNS) released under stress-induced metabolism (Tonukuri et al., 2015; Aganbi et al., 2017). The activities of GST, CAT, SOD and GPx decreased in the parasitized mice prior to treatment (Table 5). The levels of GSH also reduced in the parasitized mice. MDA and NO increased significantly in the parasitized mice due to peroxidation caused by stress (Table 5). Upon the administration of the extracts, GST, CAT, SOD and GPx activities increased in the treated groups when matched with the control groups. 
Synergistic Trial Model of Four Coadministration.....

Table 3. Effect of co-administration of four antimalarial herbs on serum electrolytes levels in Plasmodium berghei-infected mice.

\begin{tabular}{lllll}
\hline Group & Sodium $(\mathbf{m g} / \mathbf{d l})$ & Calcium $(\mathbf{m g} / \mathbf{d l})$ & Phosphorus $(\mathbf{m g} / \mathbf{d l})$ & Chloride $(\mathbf{m g} / \mathbf{d l})$ \\
\hline NC & $108.0 \pm 6.78^{\mathrm{a}}$ & $5.72 \pm 1.70^{\mathrm{a}}$ & $4.80 \pm 0.84^{\mathrm{a}}$ & $114.1 \pm 2.67^{\mathrm{a}}$ \\
PC & $137.5 \pm 3.54^{\mathrm{b}}$ & $8.50 \pm 0.14^{\mathrm{b}}$ & $3.75 \pm 0.35^{\mathrm{b}}$ & $79.00 \pm 1.41^{\mathrm{b}}$ \\
AB & $119.0 \pm 1.41^{\mathrm{c}}$ & $6.95 \pm 0.35^{\mathrm{a}}$ & $4.90 \pm 1.27^{\mathrm{d}}$ & $87.40 \pm 3.68^{\mathrm{d}}$ \\
AC & $120.0 \pm 6.00^{\mathrm{c}}$ & $7.33 \pm 0.58^{\mathrm{c}}$ & $4.77 \pm 0.78^{\mathrm{d}}$ & $83.33 \pm 5.51^{\mathrm{e}}$ \\
AD & $117.0 \pm 1.41^{\mathrm{c}}$ & $7.40 \pm 0.00^{\mathrm{c}}$ & $5.20 \pm 0.85^{\mathrm{d}}$ & $75.00 \pm 7.07^{\mathrm{b}}$ \\
BC & $131.0 \pm 7.07^{\mathrm{d}}$ & $7.35 \pm 0.35^{\mathrm{c}}$ & $5.10 \pm 0.71^{\mathrm{d}}$ & $83.50 \pm 4.95^{\mathrm{e}}$ \\
BD & $130.7 \pm 9.02^{\mathrm{d}}$ & $7.03 \pm 0.25^{\mathrm{c}}$ & $4.50 \pm 0.70^{\mathrm{d}}$ & $78.00 \pm 3.46^{\mathrm{b}}$ \\
CD & $120.5 \pm 1.00^{\mathrm{c}}$ & $7.30 \pm 0.50^{\mathrm{c}}$ & $5.30 \pm 0.48^{\mathrm{d}}$ & $82.25 \pm 2.63 \mathrm{e}$ \\
STD & $112.8 \pm 40.0^{\mathrm{a}}$ & $10.00 \pm 7.12^{\mathrm{c}}$ & $7.85 \pm 0.44^{\mathrm{c}}$ & $53.50 \pm 0.60^{\mathrm{c}}$ \\
\hline
\end{tabular}

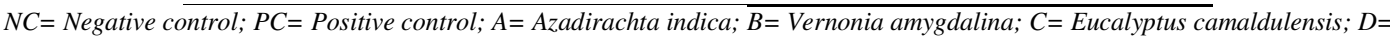
Bambusa vulgaris; STD, Standard antimalarial drug (Lonart).

Table 4. Effect of co-administration of four antimalarial herbs on liver function biomarkers in malaria-induced mice.

\begin{tabular}{lllllll}
\hline GROUP & ALT (U/L) & AST (U/L) & ALP (U/L) & GGT (U/L) & TB (mg/dl) & DB (mg/dl) \\
\hline NC & $22.80 \pm 4.34^{\mathrm{a}}$ & $46.66 \pm 3.58^{\mathrm{a}}$ & $40.92 \pm 6.05^{\mathrm{a}}$ & $83.00 \pm 2.00^{\mathrm{a}}$ & $0.72 \pm 0.08^{\mathrm{a}}$ & $0.72 \pm 0.15^{\mathrm{a}}$ \\
PC & $15.30 \pm 0.14^{\mathrm{b}}$ & $48.10 \pm 2.82^{\mathrm{a}}$ & $60.88 \pm 17.9^{\mathrm{b}}$ & $87.50 \pm 14.8^{\mathrm{b}}$ & $1.95 \pm 2.76^{\mathrm{b}}$ & $1.45 \pm 0.91^{\mathrm{a}}$ \\
AB & $15.10 \pm 1.41^{\mathrm{b}}$ & $42.65 \pm 3.61^{\mathrm{c}}$ & $44.54 \pm 7.92^{\mathrm{d}}$ & $77.00 \pm 10.0^{\mathrm{d}}$ & $2.70 \pm 1.70^{\mathrm{d}}$ & $1.25 \pm 0.07^{\mathrm{a}}$ \\
AC & $15.57 \pm 0.72^{\mathrm{b}}$ & $39.83 \pm 3.09^{\mathrm{c}}$ & $60.03 \pm 14.7^{\mathrm{b}}$ & $79.00 \pm 9.54^{\mathrm{d}}$ & $1.57 \pm 0.90^{\mathrm{b}}$ & $1.43 \pm 0.25^{\mathrm{a}}$ \\
AD & $17.65 \pm 0.64^{\mathrm{b}}$ & $34.60 \pm 6.51^{\mathrm{d}}$ & $68.27 \pm 20.7^{\mathrm{e}}$ & $76.50 \pm 9.19^{\mathrm{d}}$ & $0.60 \pm 0.71^{\mathrm{a}}$ & $1.20 \pm 0.57^{\mathrm{a}}$ \\
BC & $16.25 \pm 3.04^{\mathrm{b}}$ & $56.60 \pm 9.33^{\mathrm{c}}$ & $59.09 \pm 7.38^{\mathrm{b}}$ & $83.50 \pm 4.95^{\mathrm{a}}$ & $3.15 \pm 1.20^{\mathrm{c}}$ & $1.50 \pm 0.71^{\mathrm{a}}$ \\
BD & $11.07 \pm 9.42^{\mathrm{c}}$ & $42.70 \pm 10.2^{\mathrm{c}}$ & $59.39 \pm 5.16^{\mathrm{b}}$ & $78.00 \pm 3.46^{\mathrm{d}}$ & $2.93 \pm 0.90^{\mathrm{d}}$ & $1.73 \pm 0.46^{\mathrm{a}}$ \\
CD & $16.93 \pm 2.44^{\mathrm{b}}$ & $44.25 \pm 4.79^{\mathrm{c}}$ & $47.44 \pm 2.12^{\mathrm{b}}$ & $81.25 \pm 2.50^{\mathrm{a}}$ & $2.65 \pm 1.81^{\mathrm{d}}$ & $1.33 \pm 0.79^{\mathrm{a}}$ \\
STD & $17.00 \pm 0.00^{\mathrm{b}}$ & $20.80 \pm 1.01^{\mathrm{b}}$ & $33.65 \pm 4.22^{\mathrm{c}}$ & $42.95 \pm 4.02^{\mathrm{c}}$ & $3.88 \pm 0.30^{\mathrm{c}}$ & $1.08 \pm 0.71^{\mathrm{a}}$
\end{tabular}

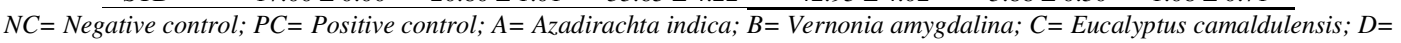
Bambusa vulgaris; STD, Standard antimalarial drug (Lonart). ALT, Alanine aminotransferase activity; AST, Aspartate aminotransferase activity; ALP, Alkaline phosphatase activity; GGT; Gamma glutarmyl-S-transferase activity; TB, Total bilirubin level; DB, Direct bilirubin level.

Table 5: Effect of co-administration of four antimalarial herbs on antioxidant status of liver of malaria-induced mice.

\begin{tabular}{|c|c|c|c|c|c|c|c|}
\hline GROUP & $\begin{array}{l}\text { GST } \\
\text { (U/g tissue) }\end{array}$ & $\begin{array}{l}\text { CAT } \\
\text { (U/g tissue) }\end{array}$ & $\begin{array}{l}\mathrm{SOD} \\
\text { (U/g tissue) }\end{array}$ & $\begin{array}{l}\text { MDA } \\
\text { (U/g tissue) } \times 10^{-3}\end{array}$ & $\begin{array}{l}\text { GPx } \\
\text { (U/g tissue) }\end{array}$ & $\begin{array}{l}\text { GSH } \\
\text { (U/g tissue) }\end{array}$ & $\begin{array}{l}\text { NO } \\
\text { ( } \mathrm{kM} / \mathrm{g} \text { tissue) }\end{array}$ \\
\hline $\mathrm{NC}$ & $10.20=1.64$ & $3.27 \pm 0.25=$ & $3.84=0.14$ & $4.49 \pm 0.71=$ & $8.72 \pm 0.03=$ & $53.90=2.33^{2}$ & $14.02=1.54$ \\
\hline $\mathrm{PC}$ & $3.79 \pm 0.13$ & $2.16 \pm 0.04$ & $0.06=$ & $40.5 \pm 0.51 b$ & $.15^{b}$ & $1.25^{\circ}$ & $3.38=$ \\
\hline$A B$ & $3.77 \pm 0.48^{\circ}$ & $3.19=$ & $.07^{\circ}$ & $3.36=$ & $98^{e}$ & $50.07=$ & $1.69=$ \\
\hline $\mathrm{AC}$ & $6.11 \pm 1.85^{\circ}$ & $3.24 \pm 0.71^{=}$ & $0.03^{2}$ & $3.80=1.36^{\circ}$ & $.57^{6}$ & $2 \pm 14.5^{e}$ & $16.41=1.90^{d}$ \\
\hline $\mathrm{AD}$ & $1.78^{4}$ & $3.45=$ & 3.7 & $10.83=$ & $.15^{\mathrm{d}}$ & $=3.72^{d}$ & $0.82=$ \\
\hline$B C$ & $+777=$ & $3.13=$ & $32=$ & $7.56=$ & $.74=$ & $4.6=$ & $35.44 \pm 28.2=$ \\
\hline$B D$ & $23^{2}$ & 3.2 & $.87^{6}$ & 4.89 & $37^{*}$ & $54^{6}$ & $43^{2}$ \\
\hline $\mathrm{CD}$ & & $3.52 \pm 0.18=$ & 3.2 & 8.97 & $50^{\circ}$ & $=8.55^{\circ}$ & $15.51 \pm 5.02^{a}$ \\
\hline STD & $6.46 \pm 1.90=$ & $3.49 \pm 0.15=$ & $3.39 \pm 0.12$ & $4.35=1.70=$ & $6.03=0.89 e$ & $29.96 \pm 5.19$ & $19.08 \pm 5.85^{f}$ \\
\hline
\end{tabular}

$N C=$ Negative control $; P C=$ Positive control; $A=$ Azadirachta indica $; B=$ Vernonia amygdalina $; C=$ Eucalyptus camaldulensis; $D=$ Bambusa vulgaris; STD, Standard antimalarial drug (Lonart).

The same was observed with the levels of GSH. The reverse was the levels of MDA and NO in the treated animals. This may be due to the antioxidant properties of the extracts as these plants have been previously reported to be rich phenolic compounds (Orororo et al., 2014; Anigboro et al., 2014; Tonukari et al., 2015a, 2015b). The findings of this study are also consistent with the reports of Iweala et al., (2013) and Sugumar et al., (2016).

Nephrotoxicity can be evaluated by considering the levels of urea, creatinine and uric acid in serum (Aganbi et al., 2015; Avwioroko et al., 2016). There was an elevated level of these parameters prior the treatment of the malaria infected mice. However, upon the administration of the various combined extracts, the levels of urea, creatinine and uric acid reduced when compared with the positive group (Table 6).
Table 6. Effect of co-administration of four antimalarial herbs on serum creatinine, urea and uric acid levels in malaria-induced mice.

\begin{tabular}{llll}
\hline Group & $\begin{array}{l}\text { Creatinine } \\
(\mathbf{m g} / \mathbf{d l})\end{array}$ & $\begin{array}{l}\text { Urea } \\
(\mathbf{m g} / \mathbf{d l})\end{array}$ & $\begin{array}{l}\text { Uric acid } \\
(\mathbf{m g} / \mathbf{d l})\end{array}$ \\
\hline $\mathrm{NC}$ & $1.14 \pm 0.40^{\mathrm{a}}$ & $24.33 \pm 2.41^{\mathrm{a}}$ & $4.90 \pm 1.74^{\mathrm{a}}$ \\
$\mathrm{PC}$ & $2.20 \pm 0.71^{\mathrm{b}}$ & $50.18 \pm 22.1^{\mathrm{b}}$ & $2.35 \pm 0.49^{\mathrm{b}}$ \\
$\mathrm{AB}$ & $2.25 \pm 0.07^{\mathrm{b}}$ & $44.39 \pm 4.74^{\mathrm{c}}$ & $2.70 \pm 0.00^{\mathrm{b}}$ \\
$\mathrm{AC}$ & $2.30 \pm 0.17^{\mathrm{b}}$ & $54.47 \pm 38.6^{\mathrm{b}}$ & $2.07 \pm 0.06^{\mathrm{b}}$ \\
$\mathrm{AD}$ & $2.15 \pm 0.49^{\mathrm{b}}$ & $37.54 \pm 8.22^{\mathrm{d}}$ & $2.55 \pm 0.78^{\mathrm{b}}$ \\
$\mathrm{BC}$ & $2.45 \pm 0.49^{\mathrm{b}}$ & $48.77 \pm 8.03^{\mathrm{b}}$ & $3.00 \pm 0.00^{\mathrm{c}}$ \\
$\mathrm{BD}$ & $2.50 \pm 0.17^{\mathrm{b}}$ & $46.24 \pm 10.6^{\mathrm{b}}$ & $3.20 \pm 0.26^{\mathrm{c}}$ \\
$\mathrm{CD}$ & $2.13 \pm 0.43^{\mathrm{b}}$ & $29.49 \pm 10.0^{\mathrm{a}}$ & $3.55 \pm 0.41^{\mathrm{c}}$ \\
$\mathrm{STD}$ & $2.65 \pm 8.26^{\mathrm{b}}$ & $53.75 \pm 0.17^{\mathrm{b}}$ & $1.53 \pm 0.28^{\mathrm{c}}$ \\
\hline
\end{tabular}

$N C=$ Negative control; $P C=$ Positive control $; A=$ Azadirachta indica; $B=$ Vernonia amygdalina; $C=$ Eucalyptus camaldulensis; $D=$ Bambusa vulgaris; STD, Standard antimalarial drug (Lonart).

This an indication of renal protective role of the various combined aqueous leaf extracts $A$. indica, $V$. amygdalina, E. camaldulensis and $B$. vulgaris on inoculated mice. Thus, the synergistic action of the 
extracts has been shown to be effective in the treatment of malaria parasite in mice by reducing the parasite load. Hepato- and renal integrity were also restored by the administration of the combined extracts. Antioxidants activities also increased upon the administration of the extracts, indicating the restoration of biochemical abnormalities. It is therefore recommended that the coadministration of these locally used plants, especially at the concentrations investigated in this study, be taken for the treatment or management of malarial fever as their action is very close to that of the antimalarial drug, Lonart which was the conventional drug used in this study.

\section{REFERENCES}

Aganbi, E; Avwioroko, OJ; Enabulele, ER; Osagu, CK; Uwandu, A; Ike, A; Akpede, P; Eferusuoa (2015). Amelioration of lead-induced toxicity in blood, liver and kidney tissues of male wistar rats by fermented Ofada rice. Turkish J. Agriculture Food Sci. Technol. 3(9): 754-759.

Aganbi, E; Onyeukwu, OB; Avwioroko, OJ; Tonukari NJ (2017). Effect of fermentation on sensory, nutritional and antioxidant properties of mixtures of aqueous extracts of Hibiscus sabdariffa (Zobo) and Raphia hookeri (Raffia) wine. Nig. J. Sci. Environ. 15(1): 66 - 74.

Adeniyi, BA; Ayepola. OO; Adu, FD (2016).The antiviral activity of leaves of Eucalyptus camaldulensis (Dehn) and Eucalyptus torelliana (R. Muell). Pak. J. Pharm. Sci. 28(5): 1773-1776.

Ambika, K; Rajagopal, B (2017). In Vitro Antimicrobial and Antiproliferative Activity of Bambusa vulgaris. Ijppr. Human. 9(1): 10-22.

Anigboro, AA; Onakurhefe, P; Tonukari, NJ; Avwioroko, OJ; Egbeme, E (2014). Quantitative determination of some phytochemicals (phenol, flavonoid, saponin and alkaloid) in twenty-two Nigerian medicinal plants. Nig. J. Sci. Environ. 13(1): 86 - 93 .

Avwioroko, OJ; Anigboro, AA; Tonukari, NJ (2016). Biotechnological application of cassavadegrading fungal (CDF) amylase in broiler feed formulation. British Biotechnol. J. 10(1): 1-12.

Beutler, E; Duron, O; Kally, BM (1963). Improved method of determination of blood glutathione. $J$. Lab. Clin. Med. 61: 351-358.
Bott-Silverman, C; Aksut, B (2015). Dilated and restrictive cardiomyopathies. Clevelandclinic.http://www.clevelandclinicmede d.com/medicalpubs/diseasemanagement/cardiolo gy/dilatedrestrictive-cardiomyopathy/.

Chaisawangwong, W; Gritsanapan, W (2013). Quality assessment and scavenging activity of Siamese neem flower extract. Nat. Prod. Res. 27:394-401.

Chance, B; Maehly, AC (1955). Assay of catalase and peroxidase. Methods Enzymol. 2: 764-775.

Cissy, N; Engeu, OP; Berna, O; Norbert, A; Esther, M (2016). Artemisia annua L. and Vernonia amygdalina Del: A Potential Herbal Artemisinin Combination Treatment against Malaria. British J. Pharmaceut.. Res. 14(3): 1-7.

Ekpo, DE; Ekanemesang, UM (2016). Antiplasmodial/ antimalarial effect of ethanol extracts of leaves of Vernonia amygdalina and Gongronema latifolium on the activity of catalase in Plasmodium berghei-parasitized mice. IJBCRR 10(4): 1-9.

Ellman, GL (1951). Tissue sulfhydryl groups. Arch. Biochem. Biophys. 82: 70-77.

Iweala, EJ; Uhegbu, FO; Adesanoye, OA (2013). Biochemical effects of leaf extracts of Gongronema latifolium and selenium supplementation in alloxan induced diabetic rats. J. Pharmacognosy Phytother. 5(5): 91-97.

Kadry, SM; Mohamed, AM; Farrag, EM; Fayed, DB (2013). Influence of some micronutrients and Citharexylum quadrangular extract against liver fibrosis in Schistosoma mansoni infected mice. Afr. J. Pharm.Pharmacol. 7(38): 2628-2638.

Khan, KK; Hemalatha, E (2015). A review on the genus Bambusa and one particular species Bambusa vulgaris Sabah (Malaysia). Int. Res. J. Pharm. 6(9): 580-584.

Maan, P; Yadav, KS; Yadav, NP (2017). Wound healing activity of Azadirachta indica A. juss stem bark in mice. Phcog Mag. 13(Suppl S2): 316-20.

Mantha, SV; Prasad, M; Kalra, J; Prasad, K (1993). Antioxidant enzymes in hypercholesterolemia and effects of vitamin E in rabbits. Atherosclerosis. 101: 135-144. 
Misra, HP; Fridovich, I (1972). The role of superoxide anion in the auto-oxidation of epinephrine and a simple assay for superoxide dismutase. J. Biol. Chem. 247: 3170.

Nagpal, N; Shah, G; Arora, NM; Shri, R; Arya, Y (2010). Phytochemical and pharmacological aspects of eucalyptus genus. IJPSR. 1(12): 28-36.

Omoregie, ES; Pal, A (2016). Antiplasmodial, antioxidant and immunomodulatory activities of ethanol extract of Vernonia amygdalina del. Leaf in swiss mice. Avicenna J. Phytomed. 6 (2): 236247.

Orororo, OC; Tonukari, NJ; Avwioroko, OJ; Ezedom, $\mathrm{T}$ (2014). Effect of supplementation of animal feed with dried cassava (Manihot esculenta) peels, and stems of Vernonia amygdalina and Pennisetum purpereum on some biochemical parameters in pigs. NISEB J. 14(4): $177-183$.

Oyedeji, KO; Bolarinwa, AF; Akintola, AM (2013). Effect of methanolic extract of Vernonia amygdalina on hematological and plasma biochemical parameters in male albino rats. $J$. Dental Med. Sci. 3(5):64-67.

Sharma, H; Sarker, SJ; Lambourne, JR; Fhogartaigh, CN; Price, NM; Klein, JL (2016). The selective outpatient treatment of adults with imported falciparum malaria: a prospective cohort study. QJM. 109: 181-6.

Somsak, V; Chachiyo, S; Kittitorn, J; Audomkasok, S; Sriwiphat, S (2015). Antimalarial and Antihypoglycemic Properties of Siamese Neem Tree (Azadirachta indica) in Plasmodium berghei Infected Mice. Malar Cont. Elimination. 4: 134137.
Stanley, IO; Iguodala, AF; Henry, OB; Iyekowa, O (2013). Myocardial dysfunction: a primary cause of death due to severe malaria in a Plasmodium falciparum-humanized mouse model. Iran $J$. Parasitol. 8: 499-509.

Sugumar, M; Doss, VA; Maddisetty, PN (2016). Hepato-renal protective effects of hydroethanolic extract of Senna alata on enzymatic and nonenzymatic antioxidant systems in streptozotocin induced diabetic rats. Integr. Med. Res. 5(2 016 ): 276-283.

Takasaki, M; Konoshima, T; Fujitani, K; Yoshida, S; Nishimura, H; Tokuda, H; Nishino, H; Iwashima, A; Kozuka, M (1990). Inhibitors of skin-tumor promotion VIII. Inhibitory effects of euglobals and their related compounds on Epstein Barr virus activation (1). Chem. Pharm. Bulletin Tokyo. 38(10): 27379.

Tonukari, NJ; Avwioroko, OJ; Anigboro, AA (2015a). Effect of preservation on the chlorophyll content, phytochemicals, and antioxidant capacity of two different varieties of pumpkin (Telfairia occidentalis) leaves. Nig. J. Technol. Res. 10(1): 9-16.

Tonukari, NJ; Avwioroko, OJ; Ezedom, T; Anigboro, AA (2015b). Effect of preservation on two different varieties of Vernonia amygdalina Del. (bitter) leaves. Food Nutr. Sci. 6: 633-642.

World Health Organization (2015). Guidelines for the treatment of malaria. World Health Organization. 